\title{
The influence of soil moisture on threshold runoff generation processes in an alpine headwater catchment
}

\author{
D. Penna ${ }^{1}$, H. J. Tromp-van Meerveld ${ }^{2}$, A. Gobbi ${ }^{1}$, M. Borga ${ }^{1}$, and G. Dalla Fontana ${ }^{1}$ \\ ${ }^{1}$ Department of Land and Agroforest Environments, University of Padova, Italy \\ ${ }^{2}$ Department of Geography, Simon Fraser University, Burnaby, BC, Canada
}

Received: 11 October 2010 - Published in Hydrol. Earth Syst. Sci. Discuss.: 15 October 2010

Revised: 11 January 2011 - Accepted: 16 February 2011 - Published: 1 March 2011

\begin{abstract}
This study investigates the role of soil moisture on the threshold runoff response in a small headwater catchment in the Italian Alps that is characterised by steep hillslopes and a distinct riparian zone. This study focuses on: (i) the threshold soil moisture-runoff relationship and the influence of catchment topography on this relation; (ii) the temporal dynamics of soil moisture, streamflow and groundwater that characterize the catchment's response to rainfall during dry and wet periods; and (iii) the combined effect of antecedent wetness conditions and rainfall amount on hillslope and riparian runoff. Our results highlight the strong control exerted by soil moisture on runoff in this catchment: a sharp threshold exists in the relationship between soil water content and runoff coefficient, streamflow, and hillslope-averaged depth to water table. Low runoff ratios were likely related to the response of the riparian zone, which was almost always close to saturation. High runoff ratios occurred during wet antecedent conditions, when the soil moisture threshold was exceeded. In these cases, subsurface flow was activated on hillslopes, which became a major contributor to runoff. Antecedent wetness conditions also controlled the catchment's response time: during dry periods, streamflow reacted and peaked prior to hillslope soil moisture whereas during wet conditions the opposite occurred. This difference resulted in a hysteretic behaviour in the soil moisture-streamflow relationship. Finally, the influence of antecedent moisture conditions on runoff was also evident in the relation between cumulative rainfall and total stormflow. Small storms during dry conditions produced low stormflow amounts, likely mainly from overland flow from the near saturated riparian zone. Conversely, for rainfall events during wet conditions, higher stormflow values were observed and hillslopes must have contributed to streamflow.
\end{abstract}

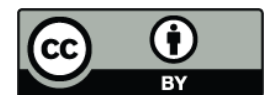

Correspondence to: D. Penna (daniele.penna@unipd.it)

\section{Introduction}

Thresholds and other non-linear behaviours are common in hydrologic and geomorphic systems. They can occur at different levels of complexity (Zehe and Sivapalan, 2009), at various spatial scales and may limit the predictability of hydrological processes (Norbiato et al., 2008) and the repeatability of hydrological observations (Zehe et al., 2007). Therefore, investigating and understanding the controls exerted by thresholds is essential to understand stream responses at the catchment scale (Tetzlaff et al., 2008). One hydrological variable frequently found to be non-linearly related to runoff is soil moisture. Early work by Western and Grayson (1998) in the Tarrawarra catchment, in South-eastern Australia, clearly showed that surface runoff was a threshold process controlled by catchment wetness conditions, with runoff coefficients abruptly increasing when a certain moisture threshold was exceeded. Similar results for the relationship between near surface soil water content and runoff were recently found by other authors (Tromp-van Meerveld and McDonnell, 2005; James and Roulet, 2007, 2009; Latron and Gallart, 2008; Zehe et al., 2010) with varying values of the moisture threshold, likely due to differences in soil type, soil depth and climatic conditions. Other investigations on hillslopes and experimental catchments have revealed the occurrence of threshold relations between soil moisture and water table variations (Peters et al., 2003; Latron and Gallart, 2008), highlighting the critical role of wetness conditions on surface and subsurface runoff generation. Sidle et al. (1995) showed that hollows or zero-order basins, which produced little or no runoff during dry conditions, contributed significantly to total catchment runoff once an antecedent moisture threshold was reached. These findings were consistent with later observations by Torres (2002), who speculated on the presence of a threshold value in the relationship between soil moisture and pressure head, above which rapid pressure head reactions occurred in the unsaturated zone, leading to quick

Published by Copernicus Publications on behalf of the European Geosciences Union. 
soil-water redistribution and fast discharge responses. Furthermore, in two recent papers Detty and McGuire (2010a, b) identified a clear threshold relationship between the sum of antecedent wetness and gross precipitation and storm runoff: below the threshold total runoff was minimal whereas above it total runoff was linearly correlated with the combination of antecedent soil moisture and rainfall.

The control exerted by wetness conditions on runoff generation has been shown to be especially important in steep, humid catchments with shallow soils, where topographic properties exert a significant role on the dominant hydrological processes (Sidle et al., 2000; McGlynn, 2005). Relatively flat areas close to the stream have the potential to store water, to quickly saturate even during small rainfall events and to rapidly deliver water to the stream network, resulting in a fast runoff response. Conversely, soil water stored in the far-stream/hillslope zones may be released only during wetter conditions, when flowpaths between the hillslope and riparian zone become connected. Experimental evidence in mountainous and agricultural catchments has revealed that riparian zones tend to respond differently and almost independently from upslope zones with runoff typically being generated first in riparian areas, and with riparian-hillslope hydrological connectivity increasing under wetter conditions (McGlynn et al., 2004; Wenninger et al., 2004; Ocampo et al., 2006). These different response times reveal distinctly different groundwater dynamics in riparian and upslope zones (Kendall et al., 1999; Seibert et al., 2003; Rassam et al., 2006), leading at times to hysteretic behaviours in the groundwater-runoff relationship (Kendall et al., 1999; McGlynn et al., 2004; Penna et al., 2010). The influence of rapid soil saturation in riparian zones on catchment runoff response has been highlighted in various studies. Investigating the runoff generation processes in a small headwater catchment in Japan, Sidle et al. (2000) identified saturated overland flow from the narrow riparian corridor as the main contributor to runoff during dry conditions whereas, as antecedent wetness increased, subsurface flow from adjacent hillslopes became the main source for streamflow with a corresponding decrease in the riparian contribution to streamflow. Burns et al. (2001) assessed the role of riparian groundwater at the Panola Mountain Research Watershed (Georgia, USA) using end-member mixing analysis and concluded that riparian groundwater was the largest component of runoff during rising streamflow and throughout stream recession. Similarly, McGlynn and McDonnell (2003) and McGlynn (2005) assessed the fundamental landscape controls on runoff generation and showed piezometric and tensiometric evidence for quicker responses to precipitation inputs of riparian zones than hillslope areas. Particularly, they found that riparian water dominated total storm runoff during small and moderate events or in early periods of large events. For larger events, hillslopes became the main contributor once runoff from the hillslope zone started, although riparian water was still more important during the hydrograph rising limb.
Along this vein of studies, this work focuses on three main questions for an experimental headwater catchment in the Italian Dolomites: (i) Is there a soil moisture threshold that controls both surface and subsurface response and how does the catchment topography affect this control? (ii) What are the main factors determining the catchment's response time during dry and wet periods? (iii) What is the combined influence of antecedent wetness condition and rainfall event size on runoff?

\section{Study area}

The study area is located in the Rio Vauz Basin $\left(1.9 \mathrm{~km}^{2}\right)$, an alpine headwater catchment located in the Italian Dolomites (central-eastern Alps, Fig. 1) with elevations ranging from 1835 to $3152 \mathrm{~m}$ a.s.l. The site features alpine climatic conditions, with a mean annual precipitation of $1220 \mathrm{~mm}$ (49\% of which is snow), and average monthly temperatures varying from $-5.7{ }^{\circ} \mathrm{C}$ in January to $14.1{ }^{\circ} \mathrm{C}$ in July. Snowmelt is the most important source of runoff in late spring but summer and early autumn storm responses significantly contribute to the flow regime. The catchment can be divided into three morphological units: (i) an upper part (3152-2200 m a.s.1.) entirely formed by Dolomitic rock cliffs, (ii) a middle part (2200-2000 ma.s.1.) composed by steep slopes and (iii) a valley bottom (2000-1835 ma.s.l.) covered by Quaternary till. As such, the Rio Vauz Basin can be deemed morphologically and hydrologically representative of headwater catchments in the Dolomitic region.

Hydro-meteorological measurements were taken in a subcatchment of the Rio Vauz Basin, named Bridge Creek Catchment (BCC, $0.14 \mathrm{~km}^{2}$ ), with elevations ranging from 1932 to $2515 \mathrm{~m}$ a.s.l. (Fig. 1). The site is densely vegetated by alpine grasslands. Trees (Norway spruce and European larch) are very rare and only form small shrubs. In the lower part of BCC, two hillslopes of similar size but different topographic shape were selected: "Piramide" $(0.46$ ha, divergentconvex) and "Emme" (0.47 ha, relatively planar). Elevations range between $1930 \mathrm{~m}$ and $1975 \mathrm{~m}$ a.s.l. for Piramide and between $1935 \mathrm{~m}$ and $1985 \mathrm{~m}$ a.s.l. for Emme. Detailed physical and chemical analyses were conducted on soil samples taken every $10 \mathrm{~cm}$ from a $70 \mathrm{~cm}$-profile dug at the toe of Piramide. The soil was classified as Cambisoil with mull, characterized by a thick layer of organic matter, strongly developed by earthworm activity. Average porosity ranged from $70.5 \%$ in the first $10 \mathrm{~cm}$ of soil to $45.0 \%$ in the deeper layers, with a mean value of $57.6 \%$ along the whole profile. Clay content decreases with depth from $73.3 \%$ to $44.4 \%$, silt content increases with depth from $15.6 \%$ to $28.3 \%$, whereas sand was the less common component, ranging between $9.2 \%$ and $1.4 \%$. Further information about the Rio Vauz Basin, its topographic characteristics and climatic conditions, and the two experimental hillslopes can be found in Penna et al. (2009) and references therein. 


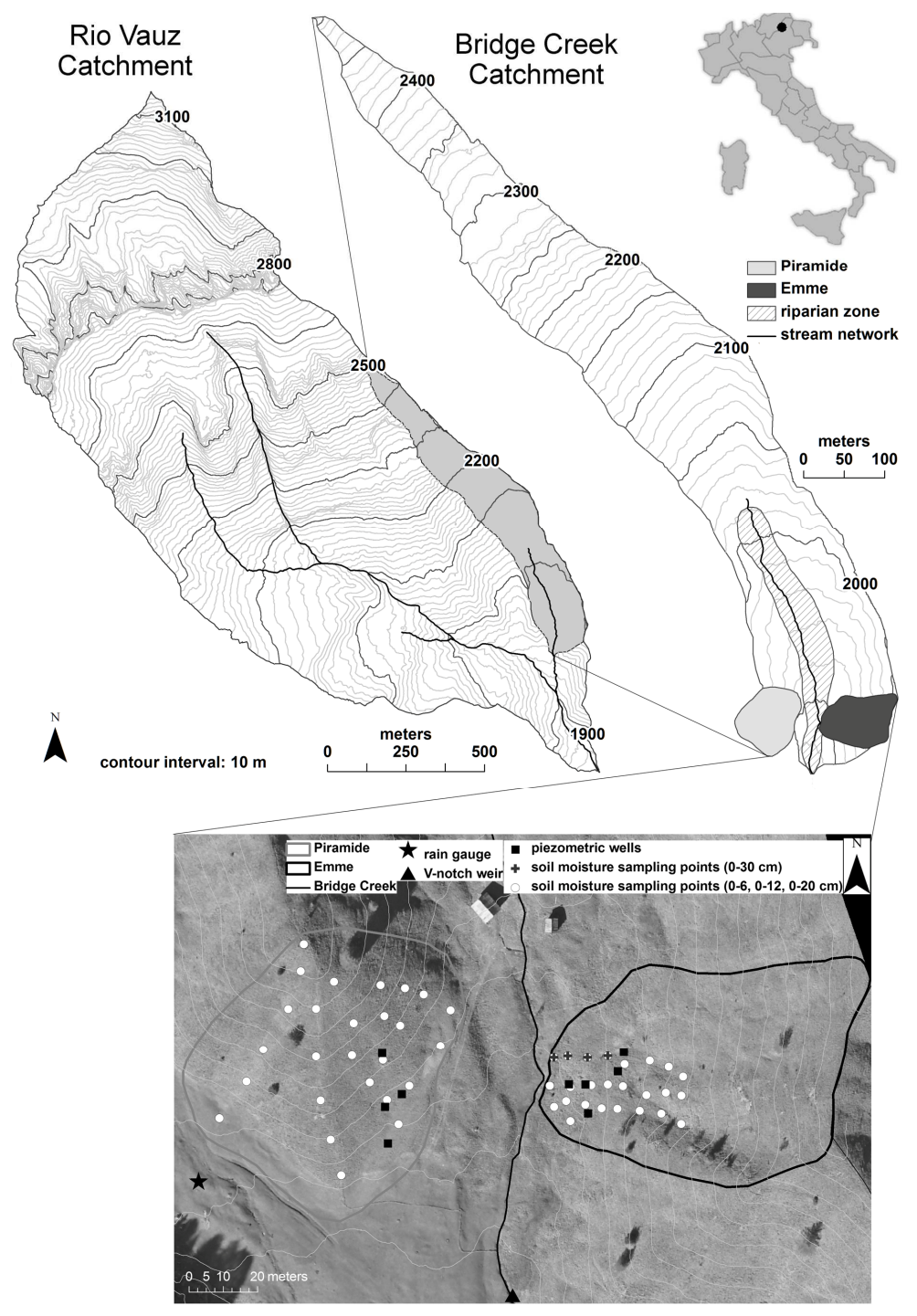

Fig. 1. Location of the study area and field instrumentation.

\section{Materials and methods}

\subsection{Precipitation, streamflow and groundwater monitoring}

Precipitation, discharge, soil moisture and groundwater data were collected at $\mathrm{BCC}$ during two monitoring periods, from 1 June to 10 October 2005 and from 1 June to 15 October 2006.

Precipitation was recorded by a tipping bucket rain gauge (Onset Computer Corporation, United States of America) located on the west of Piramide hillslope at $1943 \mathrm{~m}$ a.s.l. (Fig. 1). Discharge at BCC outlet (1932 ma.s.l.) was obtained at a V-notch sharp-crested weir equipped with a pressure transducer (Keller AG für Druckmesstechnik, Switzerland) recording at a 5-min time step. Groundwater levels were measured at nine piezometers equipped with capaci- tance water level sensors (Trutrack, New Zealand), recording at a 5-min time interval. Four piezometers were installed at Piramide and five at Emme with maximum depths ranging between 0.63 and $1.18 \mathrm{~m}$ from the soil surface (Fig. 1). Precipitation, streamflow and groundwater records were aggregated to a 15-min interval for data processing and analysis.

\subsection{Soil moisture monitoring}

Volumetric soil moisture was measured at different depths at various locations within the study area. Soil water content at $0-6 \mathrm{~cm}$ depth was manually measured on a 26 -point grid on each hillslope (Fig. 1) during several field campaigns carried out in two study periods: 28 June-21 July 2005 (24 surveys) and 21 June-16 July 2006 (23 surveys), using an impedance sensor (Theta Probe, Delta-T Devices Ltd., United Kingdom). Soil moisture at $0-12$ and $0-20 \mathrm{~cm}$ was 
Table 1. Pearson correlation coefficients for the relation between the average of the four soil moisture measurements at $0-30 \mathrm{~cm}$ and the hillslope-averaged soil moisture at three depths at Piramide and Emme for 2005 and 2006 study periods.

\begin{tabular}{l|rrr|rrrr}
\hline & \multicolumn{3}{|c|}{ Piramide } & \multicolumn{4}{c}{ Emme } \\
& $0-6 \mathrm{~cm}$ & $0-12 \mathrm{~cm}$ & $0-20 \mathrm{~cm}$ & $0-6 \mathrm{~cm}$ & $0-12 \mathrm{~cm}$ & $0-20 \mathrm{~cm}$ \\
\hline Pearson $r$ & 0.80 & 0.79 & 0.90 & 0.74 & 0.72 & 0.83 \\
\hline number of measurements & 47 & 47 & 31 & 48 & 48 & 39 \\
\hline
\end{tabular}

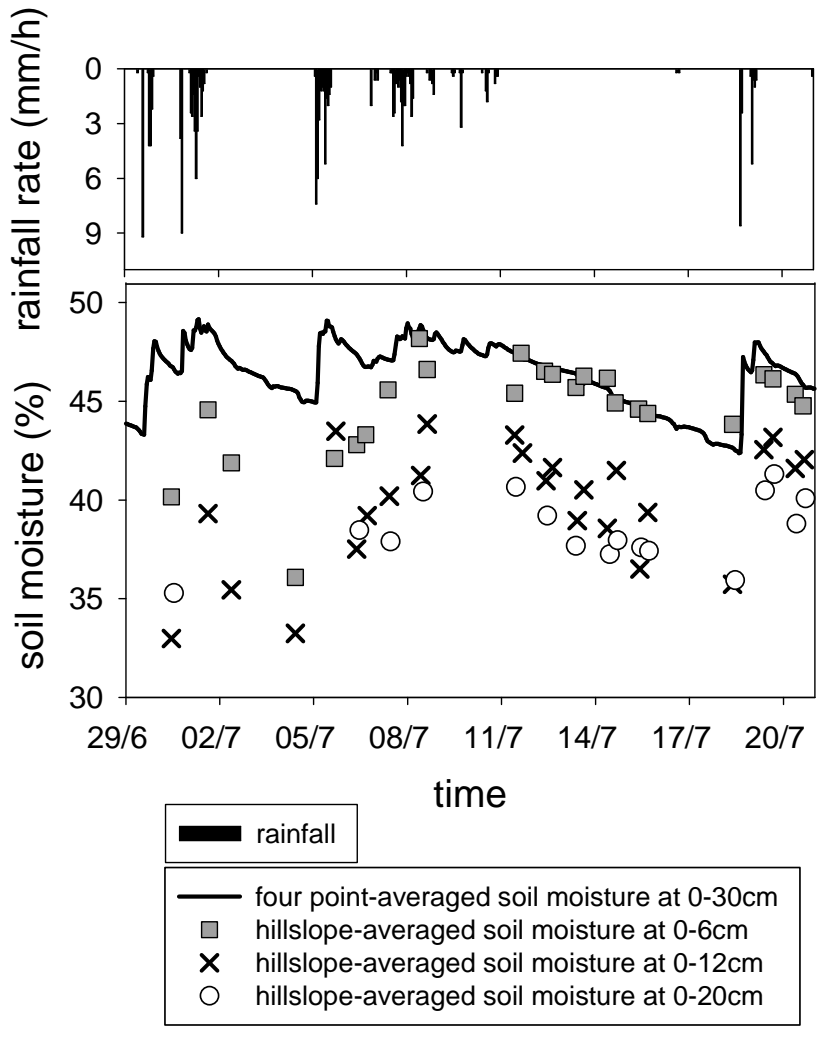

Fig. 2. Time series of four point-averaged soil moisture at $0-30 \mathrm{~cm}$ (uncalibrated) and hillslope-averaged soil moisture at 0-6, 0-12 and $0-20 \mathrm{~cm}$ depth (calibrated) for Emme during the 2005 field campaign.

measured during the field campaigns at the same sampling points using a portable Time Domain Reflectometry probe (TDR 300, Spectrum Technologies Inc., United States of America), equipped with two pairs of interchangeable rods 12 and $20 \mathrm{~cm}$ long. Soil moisture at $0-30 \mathrm{~cm}$ depth was continuously monitored at hourly time steps with Time Domain Reflectometers (CS625, Campbell Scientific, United Kingdom) at four sites located in the lower hillslope zone at Emme (Fig. 1). The Theta Probe and TDR300 measurements were calibrated for the local soil conditions against 55, 45 and 40 soil cores collected at the three investigated depths, using a split tube soil sampler. It was not possible to collect undis- turbed soil cores at $0-30 \mathrm{~cm}$ due to compaction of the samples. Thus, the standard calibration equation provided by the manufacturer for clay soils was used.

Pearson correlation coefficients were computed for the relationship between the average of the four measurements at $0-30 \mathrm{~cm}$ and the hillslope-averaged soil moisture at Piramide and Emme during the two study periods (Table 1). Despite the different sampling depths, all correlation coefficients were statistically significant $(\alpha=0.01)$ revealing a marked consistency between the measurements. The good agreement was also confirmed by comparing the time series of the average of the measurements at $0-30 \mathrm{~cm}$ with the temporal patterns of hillslope-averaged soil moisture derived from the 26 sampling points at the three depths for each experimental hillslope. An example is shown in Fig. 2. The higher soil moisture values of the $0-30 \mathrm{~cm}$ series compared to those at the other depths are due to the different sampling volume and lack of a soil specific calibration for the TDR sensors. In any case, the figure shows clearly the concordance between the temporal patterns. Moreover, a marked temporal stability of the soil moisture spatial patterns was found for the two sites (Penna et al., 2007). These observations allowed us to consider the average of the four measurements at $0-30 \mathrm{~cm}$ representative of the soil water content of the hillslope zone at BCC. Further information on the soil moisture measurements can be found in Penna et al. (2009).

\subsection{Selection of rainfall-runoff events}

To analyze the catchment's response to precipitation and the influence of soil moisture on runoff processes, 40 rainfallrunoff events during the two monitoring periods were identified. Storms were defined as events with more than $6 \mathrm{~mm}$ of precipitation. Events were considered distinct if they were separated by at least $6 \mathrm{~h}$ of no precipitation. For each event, the flood hydrograph was separated into baseflow and stormflow using the constant-k method proposed by Blume et al. (2007), with the only difference being that the break in slope in the recession that identified the end of stormflow was determined visually and not analytically. Baseflow was subtracted from total flow to compute the event runoff coefficients, defined as the ratio between event stormflow (in $\mathrm{mm}$ ) and total rainfall (in $\mathrm{mm}$ ). The events were generally characterized by relatively short and intense convective storms but a 
Table 2. Properties of selected rainfall-runoff events. The runoff coefficient had a mean of 0.15 , a coefficient of variation of 1.05 , and a skewness of 1.71 .

\begin{tabular}{|c|c|c|c|c|c|}
\hline Date & $\begin{array}{l}\text { total rainfall } \\
(\mathrm{mm})\end{array}$ & $\begin{array}{r}\text { duration } \\
\text { (h) }\end{array}$ & $\begin{array}{r}\text { total stormflow } \\
(\mathrm{mm})\end{array}$ & $\begin{array}{r}\text { peak discharge } \\
\left(1 \mathrm{~s}^{-1}\right)\end{array}$ & $\begin{array}{r}\text { runoff coefficient } \\
(-)\end{array}$ \\
\hline 12 Jun 2005 & 10.4 & 3.0 & 0.3 & 8.1 & 0.03 \\
\hline 14 Jun 2005 & 9.0 & 16.5 & 1.6 & 9.4 & 0.18 \\
\hline 24 Jun 2005 & 23.2 & 1.7 & 0.6 & 14.7 & 0.03 \\
\hline 25 Jun 2005 & 6.8 & 0.5 & 0.1 & 8.7 & 0.02 \\
\hline 29 Jun 2005 & 20.4 & 8.2 & 1.0 & 13.4 & 0.05 \\
\hline 30 Jun 2005 & 38.4 & 19.7 & 14.7 & 48.8 & 0.38 \\
\hline $05 \mathrm{Jul} 2005$ & 32.0 & 12.5 & 9.3 & 39.3 & 0.29 \\
\hline 7 Jul 2005 & 27.4 & 32.7 & 13.8 & 37.4 & 0.50 \\
\hline 18 Jul 2005 & 11.0 & 1.2 & 0.2 & 14.1 & 0.02 \\
\hline $23 \mathrm{Jul} 2005$ & 12.4 & 5.7 & 0.3 & 13.5 & 0.03 \\
\hline 13 Aug 2005 & 11.8 & 6.0 & 0.3 & 11.2 & 0.03 \\
\hline 14 Aug 2005 & 13.8 & 3.0 & 0.5 & 14.5 & 0.04 \\
\hline 18 Aug 2005 & 14.6 & 2.7 & 0.8 & 16.6 & 0.06 \\
\hline 20 Aug 2005 & 58.8 & 67.5 & 19.3 & 26.2 & 0.33 \\
\hline 3 Sep 2005 & 28.0 & 7.5 & 1.4 & 21.9 & 0.05 \\
\hline 9 Sep 2005 & 15.2 & 4.7 & 1.9 & 21.2 & 0.13 \\
\hline 17 Sep 2005 & 35.8 & 67.5 & 11.0 & 24.5 & 0.31 \\
\hline 29 Sep 2005 & 12.0 & 8.7 & 1.4 & 15.8 & 0.11 \\
\hline 1 Oct 2005 & 134.2 & 126.2 & 92.5 & 78.9 & 0.69 \\
\hline 29 Jun 2006 & 22.4 & 11.3 & 1.7 & 21.3 & 0.08 \\
\hline 2 Jul 2006 & 8.0 & 2.0 & 0.2 & 9.7 & 0.02 \\
\hline 5 Jul 2006 & 17.4 & 5.3 & 0.9 & 19.3 & 0.05 \\
\hline 6 Jul 2006 & 14.2 & 12.5 & 3.1 & 21.3 & 0.22 \\
\hline 9 Jul 2006 & 14.8 & 8.5 & 2.4 & 23.3 & 0.16 \\
\hline 27 Jul 2006 & 13.2 & 2.8 & 0.3 & 13.8 & 0.03 \\
\hline $31 \mathrm{Jul} 2006$ & 11.6 & 1.3 & 0.5 & 15.9 & 0.05 \\
\hline 1 Aug 2006 & 17.0 & 8.3 & 1.6 & 16.3 & 0.09 \\
\hline 2 Aug 2006 & 52.0 & 40.3 & 21.7 & 60.9 & 0.42 \\
\hline 9 Aug 2006 & 15.2 & 6.3 & 0.5 & 14.6 & 0.03 \\
\hline 10 Aug 2006 & 10.8 & 4.8 & 1.2 & 15.9 & 0.11 \\
\hline 11 Aug 2006 & 24.8 & 30.8 & 7.9 & 25.2 & 0.32 \\
\hline 14 Aug 2006 & 8.8 & 7.0 & 1.7 & 21.4 & 0.20 \\
\hline 16 Aug 2006 & 17.4 & 17.5 & 3.7 & 23.7 & 0.21 \\
\hline 17 Aug 2006 & 12.4 & 10.0 & 1.1 & 21.5 & 0.09 \\
\hline 25 Aug 2006 & 9.8 & 4.3 & 0.3 & 14.8 & 0.03 \\
\hline 26 Aug 2006 & 26.6 & 5.3 & 4.9 & 39.0 & 0.18 \\
\hline 7 Sep 2006 & 21.8 & 7.5 & 0.8 & 18.7 & 0.04 \\
\hline 15 Sep 2006 & 56.6 & 15.3 & 8.4 & 53.4 & 0.15 \\
\hline 16 Sep 2006 & 11.8 & 8.8 & 1.4 & 20.8 & 0.12 \\
\hline 14 Oct 2006 & 10.4 & 3.0 & 0.3 & 11.6 & 0.02 \\
\hline
\end{tabular}

long autumn rainfall event (1-4 October 2005) was recorded as well. Total event precipitation ranged between 6.8 and $134.2 \mathrm{~mm}$. The main characteristics of the selected rainfallrunoff events are given in Table 2 . The water content reflectometers were re-installed in the study area on 28 June 2005 , therefore soil moisture data at $0-30 \mathrm{~cm}$ were not available for the first four events in 2005.

\subsection{Determination of the size of the riparian area}

In high elevation, small headwater catchments, the marked topographic features allow for relatively easy determination of the fundamental landscape units. At BCC, we assessed the extent of the riparian zone by combining field surveys and DEM analysis, partially following the procedure suggested by McGlynn and Seibert (2003). We used a $1 \mathrm{~m}$ resolution Digital Elevation Model derived from a LIDAR dataset. We 

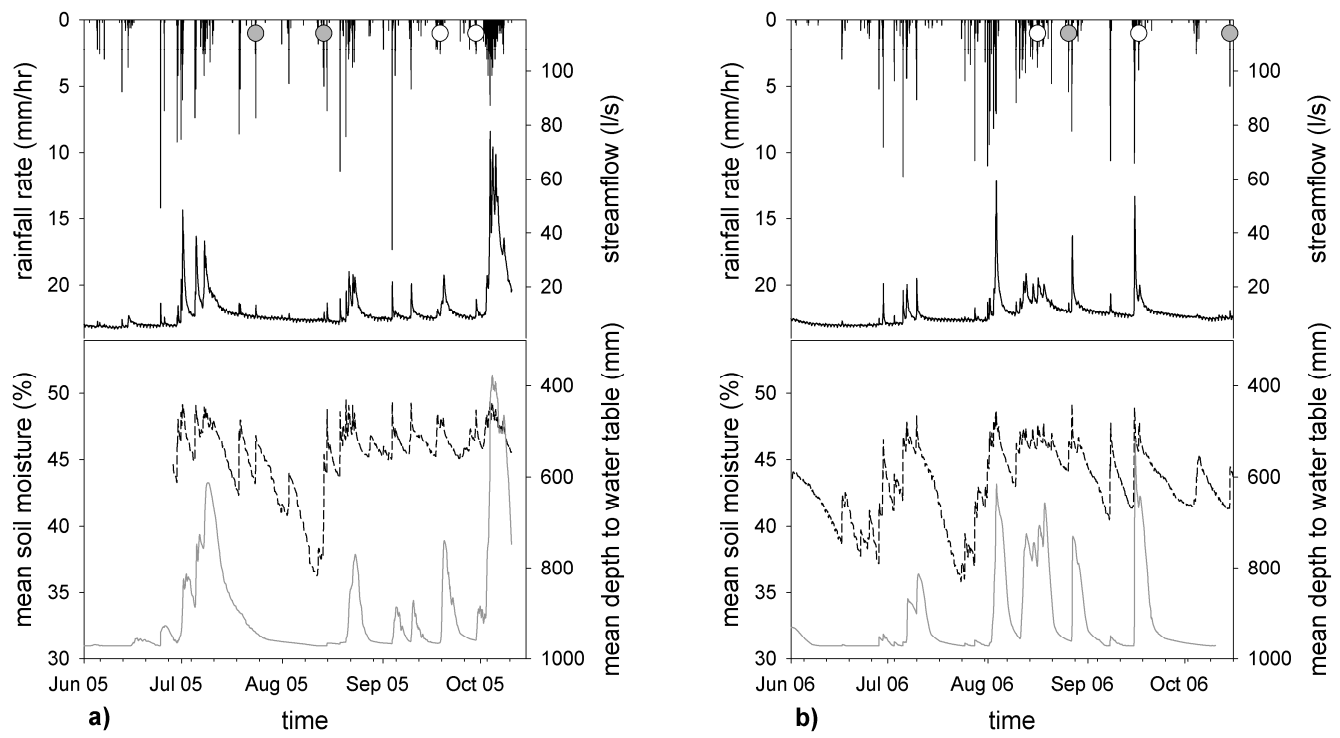

\begin{tabular}{|l|l|}
\hline rainfall & streamflow \\
\hline & ---- soil moisture $0-30 \mathrm{~cm}$ \\
\hline & depth to water table \\
\hline
\end{tabular}

Fig. 3. Hourly time series of streamflow, mean soil moisture and hillslope-averaged depth to water table for the 2005 (a) and 2006 (b) study periods. Gray and white circles represent the events with dry and wet antecedent conditions respectively shown in Fig. 8 .

chose a slope threshold value greater than the mean longitudinal slope of the stream channel and less than the ridge slope. By visually assessing the slope distribution over the whole catchment based on orthophotos and hillshade representations, we indentified a value of $15^{\circ}$ as the threshold to distinguish between grid cells belonging to the riparian zone (cell value below the threshold slope) and grid cells belonging to the hillslope zone (cell value above the threshold slope). The results from the DEM analysis were compared in the field with the real topography, walking the whole stream length and mapping the relatively flat zones characterized by wet soils. The two approaches gave similar results, yielding a riparian zone that was approximately 1.2 ha or $8.6 \%$ of the total catchment area (Fig. 1). This value for the size of the riparian area was used to assess the maximum potential riparian contribution to stormflow, as discussed in Sect. 4.4.

\section{Results and discussion}

\subsection{Time series of streamflow, soil moisture and water table}

Figure 3 shows the time series of streamflow, average soil moisture and water table for the two study periods. The total cumulative precipitation from 1 June to 10 October was $647 \mathrm{~mm}$ and $500 \mathrm{~mm}$ for 2005 and 2006 respectively, whereas the 18-year average cumulative precipitation for the same period in this region was $588 \mathrm{~mm}$. Total runoff was $561 \mathrm{~mm}$ in 2005 and $428 \mathrm{~mm}$ in 2006 and the average runoff for the same period at BCC (computed over four years) was
$473 \mathrm{~mm}$. This reveals that 2005 was a relatively wet period and, conversely, 2006 was slightly drier than average. Generally, maximum rainfall intensities were also higher in 2005 than in 2006 and events were associated with moderately short storms. The catchment's hydrological response was similar for the two years, yielding a comparable number of rainfall-runoff events (19 and 21, in 2005 and 2006 respectively). A low flow period between mid-July and the beginning of August (usually, the driest and warmest period of the year) was observed in both time series. Generally, streamflow and soil water content were highly reactive, showing marked fluctuations over the entire period and rapid, sharp responses, even to small rainfall events. Conversely, groundwater response was characterized by smoother variations, especially during recession periods (Fig. 3). A large storm event occurred at the beginning of October 2005, triggering a large hydrometric and piezometric response.

\subsection{Event runoff coefficients}

Runoff coefficients were highly variable during the two study periods, with values ranging from 0.02 to 0.69 and a coefficient of variation larger than 1 (Table 2). This distribution likely reflects the variability of the storms analyzed, mostly in terms of total precipitation, storm duration, rainfall intensity and antecedent wetness conditions. The mean value (0.15) was noticeably lower than that found by Norbiato et al. (2009) for two larger catchments which include BCC (Cordevole at La Vizza, $7.3 \mathrm{~km}^{2}$, mean: 0.33; Cordevole at Saviner, $109 \mathrm{~km}^{2}$, mean: 0.28). Besides a 


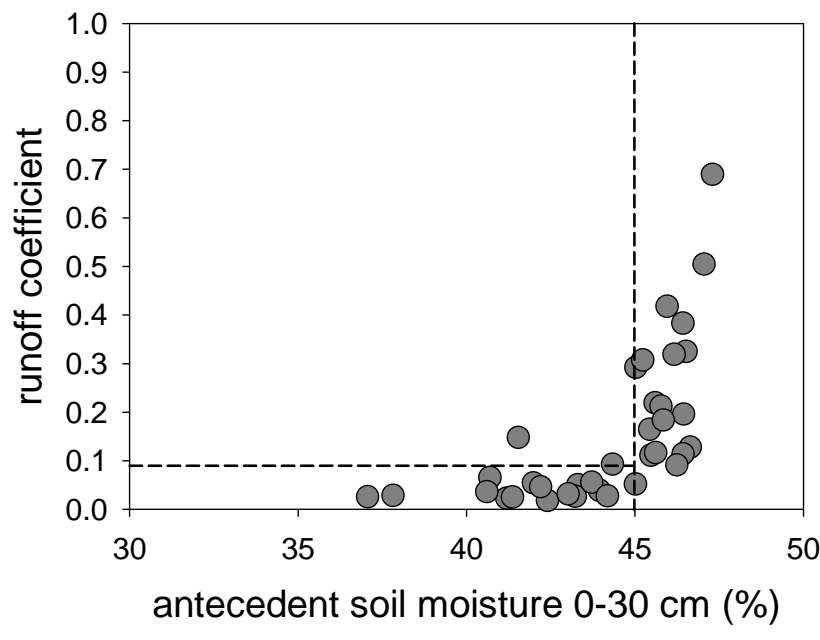

Fig. 4. Threshold behaviour in the relationship between average soil moisture at $0-30 \mathrm{~cm}$ prior to the event and the runoff coefficient. The vertical line highlights the soil moisture threshold, the horizontal line represents the value of the runoff coefficient corresponding to the ratio between the riparian area and total catchment area.

different calculation method, this was likely due to a different selection of runoff events. Investigations are on going to identify scale dependency in the different distributions of runoff coefficients.

\subsection{Relation between soil moisture and runoff}

The relationship between antecedent soil moisture at 0 $30 \mathrm{~cm}$ (defined as the mean of the four measurements taken before the storm onset) and the runoff coefficients for the 40 rainfall-runoff events during the study period was strongly non-linear and allowed the identification of a soil moisture threshold value (approximately 45\%) above which runoff significantly increased (Fig. 4). This behaviour was very similar to that found in other catchments with different topographic, climatic and land use characteristics: smooth undulating hills and temperate climate in Tarrawarra, Australia (Western and Grayson, 1998), low-elevation mountain grassland with a Mediterranean semi-humid climate in Colorso, Central Italy (Brocca et al., 2005), significant topographic relief and a humid climate in Mont Saint-Hilaire, Canada (James and Roulet, 2007), and gentle agro-forested terrain with a sub-humid climate at Fiumarella of Corleto, Southern Italy (Onorati et al., 2007).

A clear threshold behaviour was also observed in the soil moisture at $0-30 \mathrm{~cm}$ and streamflow relationship (Fig. 5a) and the soil moisture at $0-30 \mathrm{~cm}$ and groundwater relationship (Fig. 5b). Discharge and water table level were low during dry conditions and a sharp increase occurred when the $45 \%$ moisture threshold was exceeded. These results agree with previous findings in other experimental watersheds and hillslopes (Meyles et al., 2003; Peters et al., 2003; Latron and
Gallart, 2008) and underline the influence of soil moisture on non-linear runoff generation processes. Interestingly, the moisture value above which the hillslope average water level considerably rose was the same as for discharge, revealing the strong influence exerted by wetness conditions on both surface and subsurface response. Similar results were found at the Piramide and Emme sites for the relationships between hillslope-averaged soil moisture at 0-6, 0-12 and 0-20 cm depth and hillslope-averaged depth to water table (Fig. 6).

\subsection{Soil moisture and the contribution of the riparian zone to storm runoff}

The high elevation range and the clear distinction between the two fundamental catchment units at BCC were assumed to play an important role on streamflow generation. Disaggregating the watershed into discrete landscape units and determining the percentage of riparian and hillslope area can be used as a tool to assess the relative contribution of riparian water (event and pre-event water originating from riparian zones) and hillslope water (event and pre-event water originating from upland and hillslope zones) to total catchment runoff (McGlynn, 2005). Inspection of Fig. 4 reveals that the majority of small runoff coefficients (below the $45 \%$ soil moisture threshold), was lower than 0.09 (or 9\%). This value compared surprisingly well with the size of the riparian zone (8.6\%, see Sect. 3.4). This observation led us to speculate that low runoff ratios, derived from small storms with dry antecedent soil moisture conditions, were likely due to runoff from the riparian zone that was characterized by high soil moisture conditions and is therefore prone to rapid runoff response. When the soil moisture threshold was reached, the entire riparian zone might have become saturated and runoff coefficients close to the ratio of the riparian area to total catchment area occurred, indicating the maximum potential riparian contribution to basin runoff. During wetter conditions and larger events, when the soil moisture threshold was exceeded, higher runoff ratios occurred. For these events, the most important contribution to streamflow must have come from hillslopes, which likely became hydrologically active and started to release water once the soil moisture threshold was exceeded. We currently do not have isotopic or hydrochemical data to confirm these hypotheses but they agree with previous tracer-based results in other experimental catchments (Sidle et al., 2000; Burns et al., 2001; McGlynn and McDonnell, 2003), which describe the dominant role of the riparian zone for runoff generation during small events/early in the event and low antecedent wetness conditions and, on the other hand, the major contribution from hillslopes for larger events/later in the event during wetter conditions. The observation of runoff production due to precipitation falling onto saturated areas and expanding over time is related to the variable source area (VSA) concept (Hewlett and Hibbert, 1967) but only partially agrees with it. At BCC, saturated areas were believed to expand 

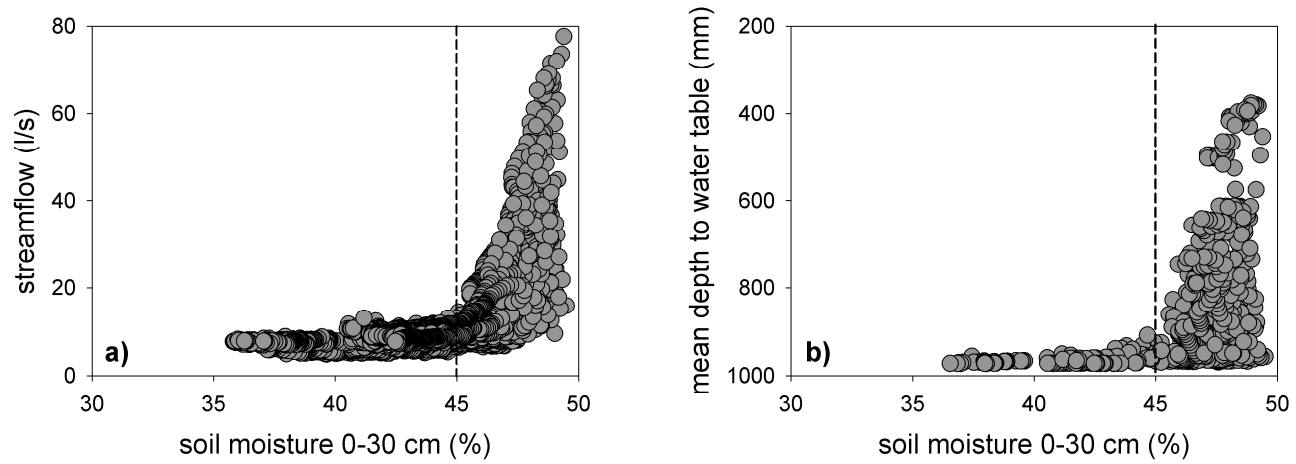

Fig. 5. Threshold behaviour in the relationship between average soil moisture and streamflow (a) and between average soil moisture and hillslope-averaged depth to water table (b).
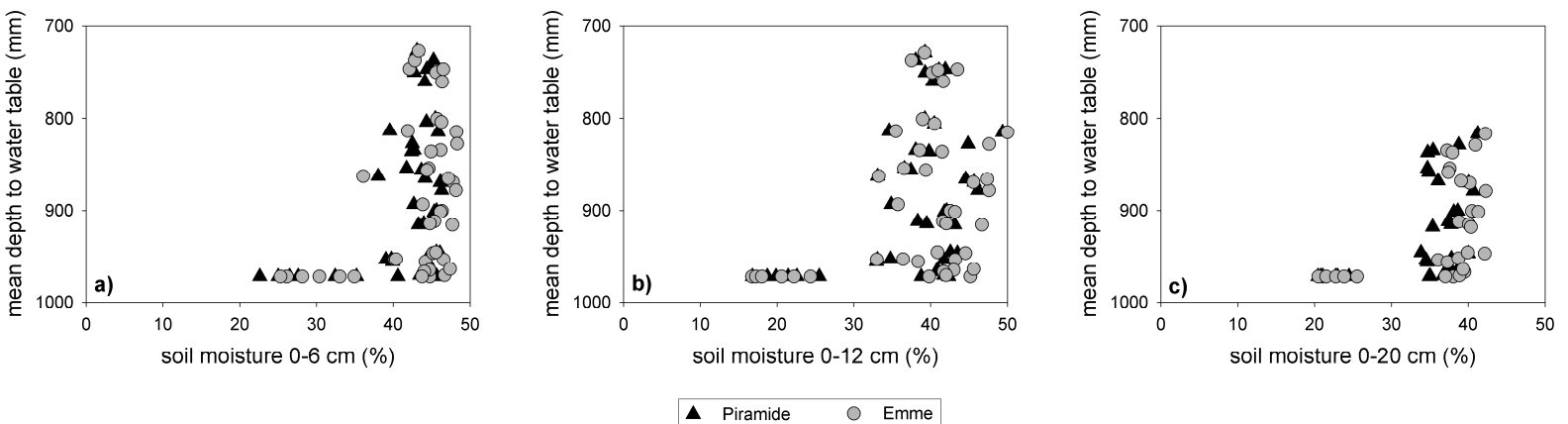

Fig. 6. Threshold behaviour in the relationship between hillslope-averaged soil moisture at $0-6 \mathrm{~cm}(\mathbf{a}), 0-12 \mathrm{~cm}(\mathbf{b}), 0-20 \mathrm{~cm}(\mathbf{c})$ and hillslope-averaged depth to water table.

from the riparian corridor to the foot of the hillslopes with increasing wetness but the threshold behaviour of hillslope activation and the subsequent abrupt increase in runoff is a mechanism not explained by the VSA concept (McDonnell, 2003). These findings, based on runoff volumes, confirm the strong control exerted by topography on runoff generation in mountain watersheds and the essential role of hillslopes and riparian zones as fundamental landscape units in determining the catchment hydrological response.

\subsection{Response time}

The temporal dynamics of the catchment's response to precipitation were investigated to better understand the dominant processes controlling the hydrological behaviour of BCC. Response times were computed following the methodology of Blume et al. (2009). Time lags between storm onset and the start and peak of soil moisture, streamflow and water table response were calculated for all rainfall-runoff events. In order to reduce the effects of storm duration (the longer the rainfall event, the longer the response time, especially to peak response), all time lag values were normalized by dividing by the time between rainfall start and water table peak (typically the longest time lag). In order to deter- mine the influence of antecedent soil moisture on the timing of the response, all events were classified into wet and dry antecedent conditions (according to the $45 \%$ soil moisture threshold) and the mean and median normalized time lags were computed for both conditions (Table 3). Overall, the observed high values of the standard deviation of the time lag indicated a marked variability of response lag time for the various events. However, distinct behaviours emerged as well. During wet conditions, (hillslope) soil moisture and streamflow on average started to rise at approximately the same time, while soil moisture peaked earlier than streamflow. Conversely, streamflow started to increase and peaked prior to (hillslope) soil moisture during dry conditions (Table 3). Hillslope-averaged water table response always exhibited a delayed start and peak, confirming previous observations in another subcatchment of the Rio Vauz Basin (Penna et al., 2010) and elsewhere (Kendall et al., 1999; McGlynn et al., 2004). Rapid soil saturation of the riparian zone could lead to a quick streamflow response (McGlynn and McDonnell, 2003) whereas deeper percolation and filling of the soil moisture deficits likely resulted in a delay of the water table response.

Two rainfall-runoff events with similar cumulative precipitation but different antecedent soil moisture conditions are 


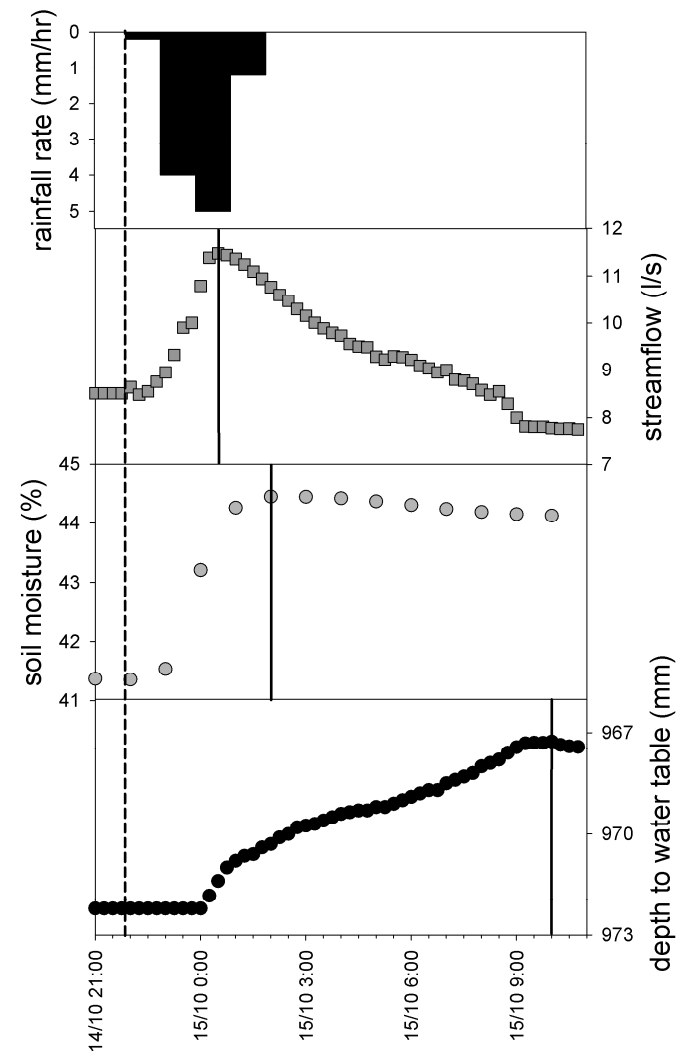

a)

time

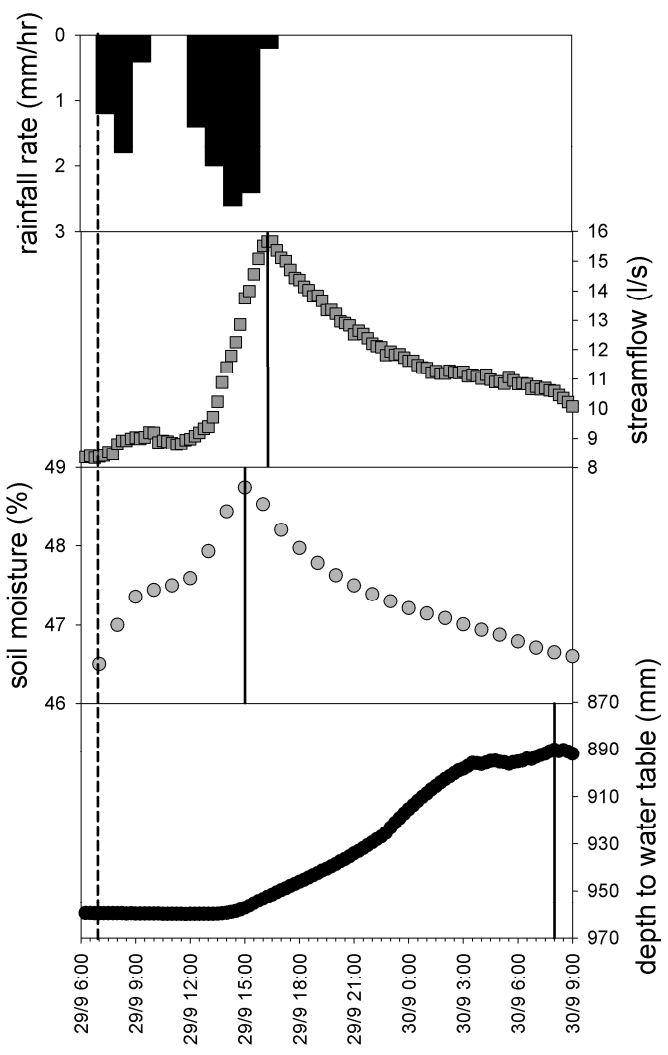

b)

time

rainfall

$\square$ streamflow

- soil moisture

- water table

Fig. 7. Time series of streamflow, average soil moisture at $0-30 \mathrm{~cm}$ and hillslope-averaged water table for (a) an event with dry antecedent conditions (14 October 2006, $10.4 \mathrm{~mm}$ of cumulative precipitation) and (b) an event with wet antecedent conditions (29 September 2005 , $12.0 \mathrm{~mm}$ of cumulative precipitation). Note the difference in scale of the axes. The vertical dashed line represents the time of the start of the rainfall event. The vertical solid lines represent the time of the peak of the response.

Table 3. Mean, median and standard deviation of time lags normalized by the peak water table time lag. SF: streamflow; SM: average soil moisture at 0-30 cm; WT: hillslope-averaged water table. Events where a water table response did not occur were excluded.

\begin{tabular}{lcccccr}
\hline & \multicolumn{7}{c}{ time lag (hours) between storm onset and: } \\
& SF start & SM start & WT start & SF peak & SM peak & WT peak \\
\hline Mean & & & & & & \\
all events & 0.12 & 0.12 & 0.28 & 0.65 & 0.62 & 1.00 \\
events in dry conditions & 0.24 & 0.25 & 0.34 & 0.73 & 0.91 & 1.00 \\
events in wet conditions & 0.06 & 0.05 & 0.24 & 0.60 & 0.46 & 1.00 \\
\hline Median & & & & & & \\
all events & 0.07 & 0.08 & 0.29 & 0.67 & 0.59 & 1.00 \\
events in dry conditions & 0.21 & 0.21 & 0.30 & 0.76 & 0.70 & 1.00 \\
events in wet conditions & 0.04 & 0.03 & 0.28 & 0.61 & 0.44 & 1.00 \\
\hline Standard deviation & & & & & & \\
all events & 0.14 & 0.15 & 0.21 & 0.29 & 0.38 & 0.00 \\
events in dry conditions & 0.19 & 0.19 & 0.24 & 0.35 & 0.43 & 0.00 \\
events in wet conditions & 0.05 & 0.04 & 0.19 & 0.25 & 0.25 & 0.00 \\
\hline
\end{tabular}



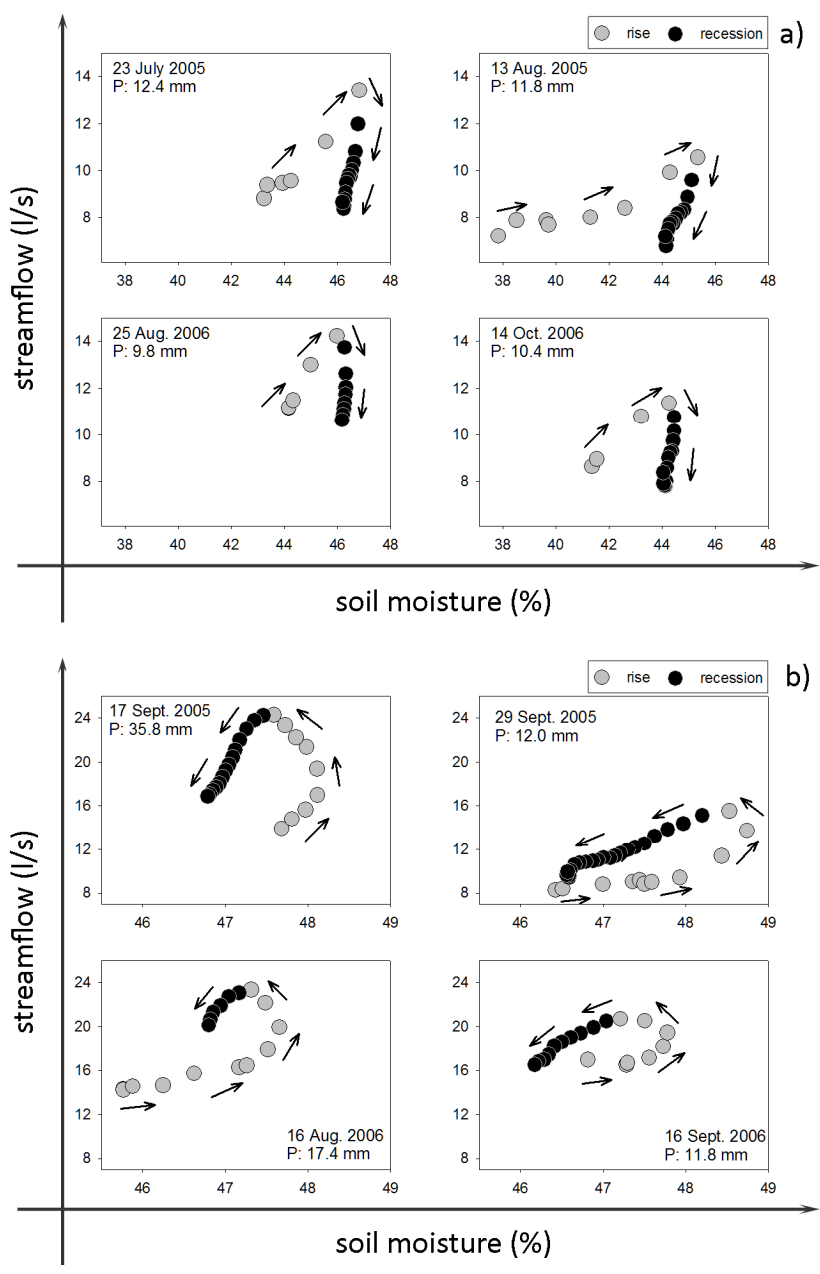

Fig. 8. Hysteretic behaviour in the relationship between average soil moisture at $0-30 \mathrm{~cm}$ and streamflow for various events with dry (a) and wet (b) antecedent conditions. $P$ : event cumulative precipitation.

compared in Fig. 7. During dry conditions (AMC $<45 \%$, panel a), soil moisture peaked after streamflow whereas during wet conditions (AMC $>45 \%$, panel b) the reverse occurred. Moreover, during dry conditions the soil moisture recession was slow, with water being retained in the soil. On the contrary, during wet conditions, reduced storage deficits and higher hydraulic conductivity facilitated the rapid displacement of water through the soil. This resulted in a faster recession and in shorter response times for events with wet conditions. These observations agree with previous findings about the different contributions of the riparian and hillslope zone to runoff: during dry periods, streamflow likely mainly increased due to channel interception and riparian runoff, resulting in peak stream discharge prior to peak hillslope soil moisture. When wetness conditions increased, hillslope runoff commenced and became the main source of catchment runoff and hillslope soil moisture peaked prior to streamflow.

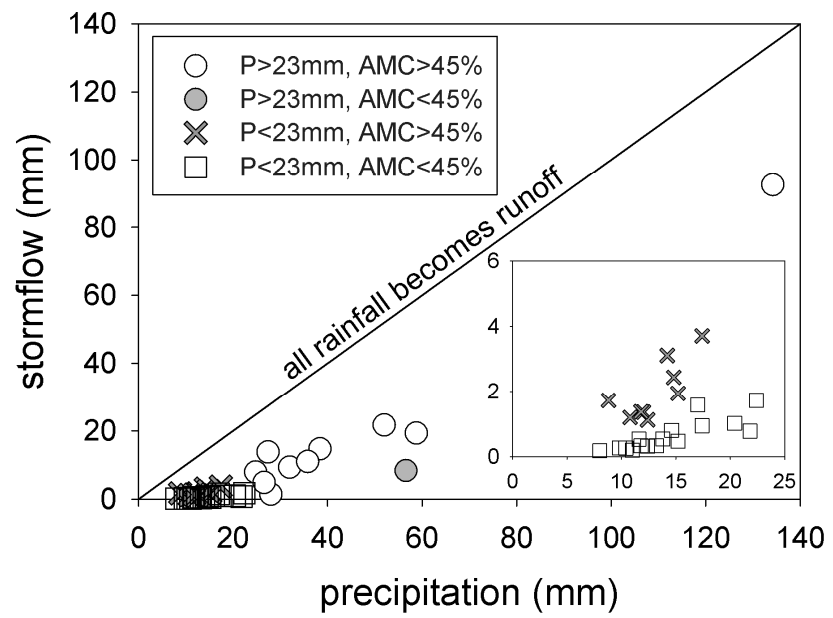

Fig. 9. Total stormflow as a function of total precipitation for all events. P: Precipitation; AMC: average Antecedent Moisture Content measured at $0-30 \mathrm{~cm}$. In the inset: zoom for the relation at low precipitation values.

The difference in timing of streamflow and soil moisture response resulted in clear hysteretic relationships between soil moisture and streamflow at BCC. Particularly, during rainfall-runoff events with dry antecedent conditions, streamflow responded and peaked earlier than hillslope soil moisture, leading to hysteretic loops with a clockwise direction (Fig. 8, panel a). For events with wet antecedent conditions, the reverse response time resulted in a hysteretic behaviour with an anticlockwise direction (Fig. 8, panel b). In the recent literature, hysteresis in hillslope and catchment response has been found in the relationship between streamflow and water table response (McGlynn et al., 2004; Beven, 2006; Ewen and Birkinshaw, 2007; Norbiato and Borga, 2008; Penna et al., 2010). A few studies have identified two opposite directions of hysteretic loops according to location (nearstream riparian zone or hillslope zone) and the difference in timing of the water table response (Kendall et al., 1999; Detty and McGuire, 2008). Moreover, very recently McGuire and McDonnell (2010) showed hillslope-streamflow hysteresis patterns that changed direction over time, as a result of increasing wetness conditions.

\subsection{Relationship between total precipitation and total stormflow}

The relationship between cumulative rainfall and total stormflow for the selected rainfall events is shown in Fig. 9. As expected, total stormflow increased with total precipitation but very small values of stormflow occurred for small events. The effect of antecedent moisture conditions on storm runoff production was assessed by dividing the 40 rainfall-runoff events into four classes based on two threshold values: $45 \%$ of soil moisture, as previously identified, and $23 \mathrm{~mm}$ of 
cumulative rainfall because stormflow appeared to significantly increase when rainfall exceeded $23 \mathrm{~mm}$. A clear combined effect of precipitation depth and antecedent soil wetness on total stormflow was observed at BCC: small events produced very low stormflow amounts during dry conditions and greater stormflow amounts during wet conditions (see inset of Fig. 9). A noticeable increase of stormflow occurred when both precipitation amount and antecedent wetness conditions increased. The best fit line through the data points had a slope of $0.09\left(R^{2}=0.66\right)$ for events smaller than $23 \mathrm{~mm}$ with dry antecedent moisture conditions $(<45 \%)$ and a slope of $0.26\left(R^{2}=0.57\right)$ for events smaller than $23 \mathrm{~mm}$ with wet antecedent moisture conditions $(>45 \%)$. The runoff coefficient for small events with dry antecedent conditions (9\%) agreed well with the size of the riparian zone ( $8.6 \%)$, as mentioned in Sect. 4.4. These results, therefore, also suggest that the runoff from the near saturated riparian zone was likely the major source of runoff during small events with dry antecedent moisture conditions but that the hillslopes must contribute to runoff during small events with wet antecedent conditions. A clear threshold in the relationship between total stormflow and total precipitation was not apparent for events with wet antecedent conditions. The slope of the linear relationship between storm total precipitation and total stormflow was $0.43\left(R^{2}=0.85\right)$ for all events with wet antecedent conditions, except the large October 2005, suggesting that total stormflow increased linearly with precipitation, that almost half of the precipitation was converted to stormflow, and that hillslopes must thus contribute to stormflow when antecedent soil moisture is high. The slope of the relationship increased to $0.70\left(R^{2}=0.94\right)$ when the large October 2005 event was included.

\section{Towards a conceptual model of hydrological behaviour at BCC}

In alpine basins with complex terrain, hydrological processes result from the interaction of several factors, including topographic, geological, pedological and climatic properties. The analyses carried out in this study helped us to better understand the dominant processes and runoff generation mechanisms controlling the hydrological response to summer rainfall events at BCC. We observed similar behaviours at BCC as those described in Sidle et al.'s (2000) conceptual hydrogeomorphic model for steep headwater catchments based on results obtained at Hitachi Ohta Experimental Watershed, Japan:

(i) During dry conditions (soil moisture at $0-30 \mathrm{~cm}$ in the $35 \%-45 \%$ range), streamflow and hillslope water table were low. Small storms resulted in low runoff coefficients (Fig. 4) and stormflow generation was likely related to the response of the near-stream riparian zone that was prone to saturation and reactive to precipitation. The increase in stormflow with precipitation was $9 \%$ of the precipitation, which sug- gested that stormflow could volumetrically be explained by the contribution of the entire riparian zone (representing approximately $9 \%$ of the total catchment area). Streamflow and soil moisture were very sensitive to rainfall inputs whereas groundwater was less reactive (Fig. 3). Streamflow response was faster than soil moisture measured on the hillslope, resulting in a clockwise hysteretic relationship between the two variables (Fig. 8a).

(ii) As wetness increased, saturation in the riparian zone likely expanded laterally to the lower parts of hillslopes that are characterized by gentle slopes and shallow soils. Experimental evidence is not available to support this view but such a behaviour could be assumed based on a comparison of the topographic and geomorphologic properties of BCC with those of the Hitachi Ohta Watershed (e.g., incised morphology, shallow soils, steep slopes).

(iii) With further increasing wetness, a moisture threshold was exceeded, resulting in a marked increase of streamflow (Fig. 5a) and likely the triggering of transient lateral subsurface flow on the hillslopes (Fig. 5b) as suggested by the abrupt increase in runoff coefficients above the $45 \%$ soil moisture threshold (Fig. 4) and the much larger increase in runoff depth with increasing precipitation (Fig. 9). A connection was likely established between the riparian area and hillslopes, which became hydrologically active zones. Response times changed compared to dry conditions: hillslope soil moisture peaked before streamflow, resulting in an anticlockwise hysteretic loop (Fig. 8b). Saturation overland flow over the hillslopes was not observed in the field during rainfall events and is assumed to be a negligible contribution to total catchment runoff. Therefore it is concluded that hillslope contributions to streamflow were most likely in the form of subsurface flow.

The information gathered in this study represents a first step toward the development of a conceptual model able to describe the hydrological behaviour of this catchment. Further investigations using isotope data and/or geochemical data (which are currently not available) will be carried out to confirm this conceptual model.

The results from the experimental data presented in this study can be useful for future research in the Dolomitic region. For instance, the assimilation of ground-based soil moisture observations, possibly coupled with remote sensing based estimates, can improve the conceptualization, the parameterization and the prediction capabilities of rainfallrunoff models (Brocca et al., 2010) developed for alpine headwater catchments. Furthermore, in mountain watersheds with hydrological behaviour similar to BCC, where a moisture threshold controls the storage-runoff relationship, the concept of competitive state variables (Duffy, 1996) might be applied and verified. In this context, the competitive inverse dependence between unsaturated and saturated moisture storage might become more important for rainfall events with increasing wetness conditions and could lead to a better comprehension of the rainfall-runoff dynamics in these 
catchments. The highly non-linear phenomena which characterize the $\mathrm{BCC}$ response represent a challenge for most hydrological models based on linearity assumptions. Moreover, the switching direction of the hysteretic loops according to antecedent moisture conditions, which reflects complex hydrological processes generated under different watershed conditions, seems to disagree with the hypothesis of catchments as simple dynamic systems (Kirchner, 2009).

\section{Conclusions}

This paper focused on the hydrological response of a small headwater catchment in the Italian Alps with a humid climate, shallow soils and a clear distinction between riparian and hillslope areas. Particularly, the critical role exerted by near-surface soil moisture on runoff generation and its influence on threshold runoff processes was assessed by examining 40 rainfall-runoff events that occurred during two summer periods. In summary, the following results were obtained:

- A clear response of soil water content and streamflow to almost any precipitation input was observed whereas the hillslope-averaged water table was less reactive, especially during dry conditions.

- A clear threshold relationship between soil moisture prior to the event and runoff was found. Above $45 \%$ volumetric soil moisture content runoff coefficients, streamflow and water table level abruptly increased revealing the strong influence exerted by initial wetness conditions on both surface and subsurface runoff. The low runoff ratios could volumetrically be explained by saturation overland flow in the riparian zone whereas the higher runoff ratios observed during wet periods required an increased contribution of hillslopes, which likely became hydrologically active once the soil moisture threshold was exceeded.

- Analysis of response times showed a quick reaction of streamflow and soil moisture while water table rise lagged behind. During dry conditions, hillslope soil moisture reacted and peaked after streamflow whereas during wet conditions hillslope soil moisture peaked before streamflow. This distinct timing difference led to a hysteretic behaviour in the soil moisture-streamflow relationship with a switch in the hysteretic loop direction based on the wetness conditions prior to the event.

- Total stormflow values showed the combined effects of antecedent conditions and precipitation. During dry conditions, small storms generated low stormflow amounts that could volumetrically be explained by contributions from the riparian zone whereas during wet conditions small storms produced more stormflow, suggesting a significant hillslope contribution.
Acknowledgements. This work was financially supported by the STREP Project HYDRATE, Contract GOCE-037024 and the Research Project GEO-RISKS (University of Padova, STPD08RWBY).

Edited by: L. Pfister

\section{References}

Beven, K.: Searching for the Holy Grail of scientific hydrology: $Q_{t}=(S, R, \Delta t)$ A as closure, Hydrol. Earth Syst. Sci., 10, 609618, doi:10.5194/hess-10-609-2006, 2006.

Blume, T., Zehe, E., and Bronstert, A.: Rainfall-runoff response, event-based runoff coefficients and hydrograph separation / Réponse pluie-débit, coefficients d'écoulement événementiels et séparation d'hydrogramme, Hydrolog. Sci. J., 52(5), 843-862, doi:10.1623/hysj.52.5.843, 2007.

Blume, T., Zehe, E., and Bronstert, A.: Use of soil moisture dynamics and patterns at different spatio-temporal scales for the investigation of subsurface flow processes, Hydrol. Earth Syst. Sci., 13, 1215-1233, doi:10.5194/hess-13-1215-2009, 2009.

Burns, D. A., McDonnell, J. J., Hooper, R. P., Peters, N. E., Freer, J. E., Kendall, C., and Beven, K.: Quantifying contribution to storm runoff through end-member mixing analysis and hydrologic measurements at the Panola Mountain Research Watershed (Georgia, USA), Hydrol. Process., 15, 1903-1924, doi:10.1002/hyp.246, 2001.

Brocca, L., Melone, F., and Moramarco, T.: Empirical and conceptual approaches for soil moisture estimation in view of eventbased rainfall-runoff modeling, in: Progress in Surface and Subsurface Water Studies at the Plot and Small Basin Scale, edited by: Maraga, F. and Arattano, M., IHP-VI, Technical Documents in Hydrology N. 77, UNESCO: Paris, 1-8, 2005.

Brocca, L., Melone, F., Moramarco, T., Wagner, W., Naeimi, V., Bartalis, Z., and Hasenauer, S.: Improving runoff prediction through the assimilation of the ASCAT soil moisture product, Hydrol. Earth Syst. Sci., 14, 1881-1893, doi:10.5194/hess-141881-2010, 2010.

Detty, J. M. and McGuire, K.: Evidence of process complexity and hydrologic threshold responses in a small headwater catchment. CUAHSI Biennial Colloquium on Hydrologic Science and Engineering: Resilience \& Vulnerability of Natural and Managed Hydrologic Systems (14-16 July, Boulder, Colorado, USA), 2008.

Detty, J. M. and McGuire, K. J.: Topographical controls on shallow groundwater dynamics: implications of hydrologic connectivity between hillslopes and riparian zones in a till mantled catchment, Hydrol. Process., Early View, doi:10.1002/hyp.7656, 2010a.

Detty, J. M. and McGuire, K. J.: Threshold changes in storm runoff generation at a till-mantled headwater catchment, Water Resour. Res., 46, W07525, doi:10.1029/2009WR008102, 2010b.

Duffy, C. J.: A two-state integral-balance model for soil moisture and groundwater dynamics in complex terrain, Water Resour. Res., 32(8), 2421-2434, 1996.

Ewen, J. and Birkinshaw, S. J.: Lumped hysteretic model for subsurface stormflow developed using downward approach, Hydrol. Process., 21, 1496-1505, doi:10.1002/hyp.6344, 2007.

Hewlett, J. D. and Hibbert, A. R.: Factors affecting the response of small watersheds to precipitation in humid areas, in: Forest 
Hydrology, Pergamon, Oxford, edited by: Sopper, W. and Lull, H. W., 1967, 275-290, 1967.

James, A. L. and Roulet N. T.: Investigating hydrologic connectivity and its association with threshold change in runoff response in a temperate forested watershed, Hydrol. Process., 21, 33913408, 2007.

James, A. L. and Roulet, N. T.: Antecedent moisture conditions and catchment morphology as controls on spatial patterns of runoff generation in small forest catchments, J. Hydrol., 377, 351-366, 2009.

Kendall, K. A., Shanley, J. B., and McDonnell, J. J.: A hydrometric and geochemical approach to test the transmissivity feedback hypothesis during snowmelt, J. Hydrol., 219, 188-205, 1999.

Kirchner, J. W.: Catchments as simple dynamical systems: Catchment characterization, rainfall-runoff modeling, and doing hydrology backward, Water Resour. Res., 45, W02429, doi:10.1029/2008WR00691285-91, 2009.

Latron, J. and Gallart, F.: Runoff generation processes in a small Mediterranean research catchment (Vallcebre, Eastern Pyrenees), J. Hydrol., 358, 206-220, 2008.

McDonnell, J. J.: Where does water go when it rains? Moving beyond the variable source area concept of rainfall-runoff response, Hydrol. Process., 17, 1869-1875, 2003.

McGlynn, B. L.: The role of riparian zone in steep mountain catchments, in: Global Change and Mountain Regions: an Overview of Current Knowledge, Adv. Global Change Res. Ser., vol. 23, edited by: Huber, U. M., Bugmann, H. K. M., and Reasoner, M. A., 331-342, Springer, NewYork, 2005.

McGlynn, B. L. and McDonnell, J. J.: Quantifying the relative contributions of riparian and hillslope zones to catchment runoff, Water Resour. Res., 39(11), 1310, doi:10.1029/2003WR002091, 2003.

McGlynn, B. L., McDonnell, J. J., Seibert, J., and Kendall, C.: Scale effects on headwater catchment runoff timing, flow sources, and groundwater-streamflow relations, Water Resour. Res., 40, W07504, doi:10.1029/2003WR002494, 2004.

McGlynn, B. L. and Seibert, J.: Distributed assessment of contributing area and riparian buffering along stream networks, Water Resour, Res., 39(4), 1082, doi:10.1029/2002WR001521, 2003.

McGuire, K. J. and McDonnell, J. J.: Hydrological connectivity of hillslopes and streams: characteristic timescales and nonlinearities, Water Resour. Res., 46, W10543, doi:10.1029/2010WR009341, 2010.

Meyles, E., Williams, A., Ternan, L., and Dowd, J.: Runoff generation in relation to soil moisture patterns in a small Dartmoor catchment, Southwest England, Hydrol. Process., 17, 251-264, 2003.

Norbiato, D., Borga, M., Degli Esposti, S., Gaume, E., and Anquetin, S.: Flash flood warning based on rainfall depth-duration thresholds and soil moisture conditions: An assessment for gauged and ungauged basins, J. Hydrol., 362(3-4), 274-290, doi:10.1016/j.jhydrol.2008.08.023, 2008.

Norbiato, D. and Borga, M.: Analysis of hysteretic behaviour of a hillslope-storage kinematic wave model for subsurface flow, Adv. Water Resour., 31, 118-131, 2008.

Norbiato, D., Borga, M., Merz, R., Blöschl, G., and Carton, A.: Controls on event runoff coefficients in the eastern Italian Alps, J. Hydrol., 375, 312-325, doi:10.1016/j.jhydrol.2009.06.044, 2009.
Ocampo, C. J., Sivapalan, M., and Oldham, C.: Hydrological connectivity of upland-riparian zones in agricultural catchments: implication for runoff generation and nitrate transport, J. Hydrol., 331, 643-658, 2006.

Onorati, B., Margiotta, M. R., Carriero, D., Manfreda, S., and Fiorentino, M.: Experimental evidence on runoff generation mechanisms. Proceedings of the AMHY-FRIEND International Workshop on Hydrological Extremes, Cosenza (Italy), 68 June 2007: Variability in space and time of extreme rainfalls, floods and droughts, 2007.

Penna, D., Borga, M., Norbiato, D., and Dalla Fontana, G.: Hillslope scale soil moisture variability in a steep alpine terrain, J. Hydrol., 364, 311-327, doi:10.1016/j.jhydrol.2008.11.009, 2009.

Penna, D., Borga, M., Sangati, M., and Gobbi, A.: Dynamics of soil moisture, subsurface flow and runoff in a small alpine basin. IAHS Publications, Red Book Series 336, ISBN 978-1-90716108-7, 96-102, 2010.

Penna, D., Norbiato, D., Borga, M., and Dalla Fontana, G.: Analisi della stabilità temporale dell'umidità del suolo in un piccolo bacino dolomitico/Temporal stability of surface soil moisture in a small alpine catchment, in: Ricerche ed esperienze di Sistemazioni Idraulico-Forestali (vol. 27, 489-502), edited by: Bischetti, G., Nuova Editoriale Bios, Cosenza, Italy, 2007.

Peters, N. E., Freer, J., and Aulenbach, B. T.: Hydrological Dynamics of the Panola Mountain Research Watershed, Georgia, Groundwater, 41, 7, Watershed Issue, 973-988, 2003.

Rassam, D. W., Fellows, C. S., De Hayer, R., Hunter, H., and Bloesch, P.: The hydrology of riparian buffer zones; two case studies in an ephemeral and a perennial stream, J. Hydrol., 325, 308-324, doi:10.1016/j.jhydrol.2005.10.023, 2006.

Seibert, J., Bishop, K., Rodhe, A., and McDonnell, J. J.: Groundwater dynamics along a hillslope: a test of the steady state hypothesis, Water Resour. Res., 39(1), 1014, doi:10.1029/2002WR001404, 2003.

Sidle, R. C., Tsuboyama, Y., Noguchi, S., Hosoda, I., Fujieda, M., and Shimizu, T.: Seasonal hydrologic response at various spatial scales in a small forested catchment, Hitachi Ohta, Japan, J. Hydrol., 168, 227-250, 1995.

Sidle, R. C., Tsuboyama, Y., Noguchi, S., Hosoda, I., Fujieda, M., and Shimizu, T.: Stormflow generation in steep forested headwaters: a linked hydrogeomorphic paradigm, Hydrol. Process., 14, 369-385, 2000.

Tetzlaff, D., McDonnell, J. J., Uhlenbrook, S., McGuire, K. J., Bogaart, P. W., Naef, F., Baird, A. J., Dunn, S. M., and Soulsby, C.: Conceptualizing catchment processes: simply too complex?, Hydrol. Process., 22, 1727-1730, doi:10.1002/hyp.7069, 2008.

Torres, R.: A threshold condition for soil-water transport, Hydrol. Process., 16, 2703-2706, doi:10.1002/hyp.5060, 2002.

Tromp-van Meerveld, H. J. and McDonnell, J. J.: Comment to Spatial correlation of soil moisture in small catchments and its relationship to dominant spatial Hydrol. Process., J. Hydrol., 286, 113-134, J. Hydrol., 303, 307-312, 2005.

Wenninger, J., Uhlenbrook, S., Tilch, N., and Leibundgut, C.: Experimental evidence of fast groundwater responses in a hillslope/floodplain area in the Black Forest Mountains, Germany. Hydrol. Process., 18(17), 3305-3322, 2004.

Western, A. W. and Grayson, R. B.: The Tarrawarra data set: soil moisture patterns, soil characteristics and hydrological flux measurements, Water Resour. Res., 34(10), 2765-2768, 1998. 
Zehe, E., Elsenbeer, H., Lindenmaier, F., Schulz, K., and Blöschl, G.: Patterns of predictability in hydrological threshold systems, Water Resour. Res., 43, W07434, doi:10.1029/2006WR005589, 2007.

Zehe, E., Graeff, T., Morgner, M., Bauer, A., and Bronstert, A.: Plot and field scale soil moisture dynamics and subsurface wetness control on runoff generation in a headwater in the Ore Mountains, Hydrol. Earth Syst. Sci., 14, 873-889, doi:10.5194/hess14-873-2010, 2010.
Zehe, E. and Sivapalan, M.: Threshold behaviour in hydrological systems as (human) geo-ecosystems: manifestations, controls, implications, Hydrol. Earth Syst. Sci., 13, 1273-1297, doi:10.5194/hess-13-1273-2009, 2009. 